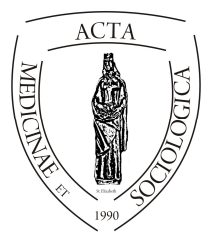

\title{
Az ápolás-és betegellátás alapszakos hallgatók karrier- aspirációit befolyásoló tényezők vizsgálata
}

\author{
Kupeczik Éva
}

hallgató, Debreceni Egyetem Egészségügyi Kar, 4400 Nyíregyháza, Sóstói út 2-4.

\begin{tabular}{|c|c|}
\hline INFO & ABSTRACT \\
\hline $\begin{array}{l}\text { Éva Kupeczik } \\
\text { kupeczik.eva@freemail.hu }\end{array}$ & \multirow[b]{2}{*}{$\begin{array}{l}\text { Factors influencing the career aspirations of students in } \\
\text { Nursing and Patient Care degree program. The Hungarian } \\
\text { health system has been experiencing and encreasing human } \\
\text { resource crisis for years, which is also found in health care } \\
\text { training at universities. } \\
\text { While prior research looked at factors underlying the } \\
\text { career aspirations of BSc nursing students, this study focuses } \\
\text { on students in three different health specializations: nursing, } \\
\text { midwife and paramedic. In all three specializations } \\
\text { individuals with the same specialization/career are more } \\
\text { frequently found among their friends/acquaintances than in } \\
\text { their families. Within the famly the mother was frequently } \\
\text { working in health care when the student decided upon their } \\
\text { career. Paramedics selected their specialization earlier than } \\
\text { midwives or nurses, however, most of the students in all three } \\
\text { specializations made their specialization/career decision } \\
\text { between age } 14 \text { and } 19 \text {. }\end{array}$} \\
\hline $\begin{array}{l}\text { Keywords } \\
\text { health system, } \\
\text { high education, } \\
\text { career choice, }\end{array}$ & \\
\hline $\begin{array}{l}\text { Kulcsszavak } \\
\text { egészségügy, } \\
\text { felsőoktatás, } \\
\text { pályaválasztás }\end{array}$ & $\begin{array}{l}\text { Absztrakt. A magyarországi egészségügyi rendszer évek óta } \\
\text { súlyosbodó humánerőforrás-krízist él át, amely megmutatkozik } \\
\text { a szakképzés terén is. Az ápolás- és betegellátás alapszakos } \\
\text { hallgatók pályaválasztási aspirációi mögött munkáló tényezök } \\
\text { feltárására irányuló kutatás (Kupeczik és Hüse, 2017; } \\
\text { Kupeczik, 2018) több szempontból körüljárta a témát-jelen ta- } \\
\text { nulmány a mintaadók szerepére fókuszál. Az adatok alapján ki- } \\
\text { jelenthető, hogy mindhárom szakirány esetében a hallgatók vá- } \\
\text { lasztott szakirányával megegyező foglalkozást betöltők na- } \\
\text { gyobb arányban jelennek meg az ismerösi/baráti köreikben, } \\
\text { mint a családjukban. A családi minta esetében túlnyomó több- } \\
\text { ségben az anya volt foglalkoztatott egészségügyi dolgozó a ta- } \\
\text { nuló továbbtanulási/pályaválasztási döntéshozatala idején. A } \\
\text { pályaválasztási elképzelések nem fogalmazódtak meg tisztán } \\
\text { szülésznő és ápoló hallgatók több mint felénél, a mentőtiszt }\end{array}$ \\
\hline
\end{tabular}


hallgatók többsége ezzel szemben pontosan tudta, milyen pálya mellett köteleződik el. A pálya melletti döntés mindhárom szakirány esetében a 14-19. életévre tehető.

Ez a tanulmány a Magyar Tudomány Ünnepén („Ember a társadalomban és az egészségügyben” - 2017. 11. 29., Debreceni Egyetem Egészségügyi Kar) elhangzott előadás alapján készült.

\section{„A hivatás az élet hátgerince.” \\ Friedrich Nietzsche}

A hazai egészségügyet érintő válság humánerőforrás-krízisének dimenziója az utóbbi években előtérbe került (Kajtor, 2003; Betlehem, 2012; Fodorné-Zagyi, 2004, Id.: Szelesné, 2016). A súlyosbító okok közül az egyik legfőbb tényező a belépő és kilépő szakképzett egészségügyi ellátók számának növekvő különbségében figyelhető meg. A probléma nem csupán az ellátórendszerben figyelhető meg, hanem már a szakemberképzés szintjén is tetten érhető. A Debreceni Egyetem Egészségügyi Kar Tanulmányi Adminisztrációs és Diáktanácsadó Iroda által az aktív státuszú hallgatókról kiadott 2016. októberi statisztikai adatok (2016/2017. tanév szeptember) szerint az első évfolyamon az öszi szemesztert 91 hallgató kezdte meg, ebből 48 mentőtiszt, 30 szülésznő, 13 ápoló szakirányon, míg a második évfolyamról összesen 84 fő (33 mentőtiszt, 34 szülésznő és 17 ápoló). Magasabb hallgatói létszámarány a harmadik (103 fó) és a negyedik (107 fó) évfolyamnál mutatkozik meg. Első esetben 31-31 ápoló és szülésznő és 41 mentőtiszt, második esetben ugyancsak 31 szülésznő, 35 ápoló, és 41 mentőtiszt hallgató folytatta tanulmányait. Habár mindhárom szakirány képzési ideje 8 félév, nagyfokú lemorzsolódást tapasztalhatunk ( 80 fö), ami a mentőtiszt szakirány hallgatóinál 30 fôt, szülésznő hallgatóknál 28 föt, ápoló hallgatóknál 22 főt érint. A lemorzsolódott hallgatók létszáma 2016. októberben csaknem megfelelt egy évfolyam létszámának. A lemorzsolódás oka nem csak a mintatantervben elöírt vizsgakövetelmények teljesítésének sikertelensége, hanem a képzésközben történő szakirányváltások is. Az alacsony hallgatói létszám, valamint a hallgatók lemorzsolódása és végleges pályaelhagyása tehát tovább súlyosbíthatja az egészségügyi ágazat foglalkoztatottjainak létszámproblémáját.

A humánerőforrás-krízisén kívül figyelembe kell venni az egészségügyi képzési területre belépő hallgatók pályaválasztási szándékainak vizsgálatát, hiszen a pályaválasztási döntések megalapozottsága, a továbbtanulási szándékok mögött meghúzódó tényezők feltárásának fontossága megkérdőjelezhetetlen (Burányné és Kun R.né, 2015).

\section{Szakirodalmi áttekintés}

A pályaválasztási vizsgálatok egyik legnehezebb része a témakör szerteágazósága, hiszen az egyén végleges döntésének meghozatalára több tényező is hatással van és befolyásolja. Éppen ezért a pályaválasztást a szakirodalom ma már nem egy egyszeri döntésnek tekinti, hanem a karriertörténetünk során meghozott kisebb-nagyobb döntések sorozataként, melyet a szociokulturális hatások alakítják a 
személyiségfejlődésünk során (N. Kollár és Szabó, 2004). Egy foglalkozás választásakor a vele járó szerepet is megválasztjuk, mely az egyén teljes szakmai életútjára hatással van, hosszú időn át tartó végzése hozzájárul az identitáshoz.

Magukat a foglalkozási szerepeket a társadalmat behálózó szervezetekben jelenlévő pozíciók adják (Csepeli, 1997), ami nem csak az előirt attitüdöket, illetve értékeket, hanem a viselkedési mintákat, vagyis egyfajta társadalmi elvárást hordoz magában, a szerep teljesítése pedig az elvárások teljesítésétől függ. Anticipáló jellegének köszönhetően alapvetően befolyásolja az egyén viselkedését, normatív jellege végett pedig segít beilleszkedni a társadalomba (Farkas és munkatársai, 2014), így valósul meg a funkcionalitása, vagyis az adott társadalomban való élés leegyszerüsítése (Banton, 1965). Mivel társadalmunk magas fokon tagolt és bonyolult munkamegosztáson alapszik, a pozíciók tárháza is széleskörü, betöltéséhez különféle speciális képesség, tudás szükséges, amit az egyénnek meg kell tanulnia (Csepeli, 2001).

Pályaválasztási szempontból az első kritikus döntési időszak a középiskola kiválasztásához köthető, ahol a család (döntést befolyásoló) ereje nagyobb, segítve a hiányzó munkatapasztalattal rendelkező, alakuló vonatkozási keretü serdülőt (Papula, 2008). A középiskola választását befolyásolhatják a serdülő érdeklődésén túl a szülők társadalmi hátteréből fakadó lehetőségek, kapcsolati tőkéjük, valamint a lakóhely és a képzési intézet közti távolság. Boudon (1974) szerint a családi háttér kiemelt hatással van az iskolaválasztásra, elsődleges ráhatását pedig a kulturális tőke átörökítésének folyamatában látta. Coleman (2000 id: Lannert, 2005) a családi hátteret pénzügyi, emberi és társadalmi tőkére bontotta, ahol az emberi tőkét a szülők iskolázottsága jelenti. A kulturális háttéren, gyermekkori anyagi körülményeken kívül az egyén életpálya alakulását befolyásolja még a szülő munkamegosztási pozíciója, valamint a lakott település háttere. Pulkinnen (1990) arra a konzekvenciára jutott, hogy a szülő foglalkozása és munkahelyének sajátossága nem csak a gyerekkel szembeni elvárásokat befolyásolja, hanem öszszefüggésben is van a serdülők terveinek egyértelmüségével. A szülők-gyerek metakogníciók pontossága a serdülők kötődési stílusának bejósló tényezője, ahogy arra Honess (2001) rámutatott. „Amellett, hogy a serdülők viszonylag pontosan észlelték a szülök nézeteit, a családtagok percepciói a serdülö lehetséges, jövőbeni munkáját illetően is magas összhangban állt egymással" (Sallay, 2003:386).

A gyermek fejlödésekor minden családon túli szociális tapasztalatot a másodlagos szocializáció folyamataiban szerzi meg, mely során a szocializációs hatások közvetítői már nem a családtagok, hanem azok a személyek, akikkel az egyén interakcióba lép a pozíciójuk vagy szerepük által, mindeközben új viszonyulásokat megismerve. Az oktatási intézményekbe történő belépés a társadalmi beilleszkedésre való felkészülés területe, hiszen az egyén megtanulhatja általa, hogyan kell olyan emberekkel optimális esetben hatékonyan müködni, akik nem a rokonai (Vajda, 2005).

Daheim a szakképzésről vagy foglalkozásról szóló döntésbe nemcsak a tanároknak, hanem a kortársak véleményének, tanácsának hatáserősségét is megnevezi (Zakar, 1998), viszont a család meghatározó szerepe a státuszigényhez kapcsolódó és a pályaválasztási kérdésekben továbbra jelentős marad (Hetheringtonetal, 1978). Ez Hotchkiss és Borow (1984, in: Okiishi, 1987) kutatásában is igazolást nyert. A serdülő pályaválasztásában meghatározó „szignifikáns másik” nemcsak a szülő és a tanár, hanem a kortársak személye is lehet, hiszen a pályaválasztási lehetőségekről való felvi- 
lágosítást a serdülö nemcsak a családtagjaitól és az iskolában oktató tanáraitól kaphatja, hanem kortársaitól is. Guay és munkatársai (2003) vizsgálatuk során arra jutottak, hogy nagyobb valószínúséggel rendelkeznek pályaválasztási önállósággal és önhatékonysági képpel azok a tinédzserek, akiknek a kortársaik támaszt nyújtottak. Azok a fiatalok, akik kortársaik felé nagyobb kötődéssel rendelkeztek, pályaválasztási lehetőségüket is alaposabban, nagyobb valószínüséggel térképezték fel (Felsman és Bluestein, 1999).

\section{Anyag és módszer}

A kutatásomban a Debreceni Egyetem Egészségügyi Kar ápolás-és betegellátás alapszak mentőtiszt, ápoló, szülésznő hallgatói vettek részt, mindösszesen 307 fö (ebből 85 ápoló, 123 mentőtiszt, 99 szülésznő hallgató, melynek $81 \%$-a nő, 19\%-a férfi). A hallgatók nem reprezentatív lekérdezése 2017. szeptember 13-20. között történt. Az alkalmazott mérőeszköz - kérdőív - négy részből épült fel, amelyben az:

a) Elsö rész

Az alapképzésen belüli meghatározásokhoz szükséges információn túl nyolc személyi kérdésből állt. Jelen tanulmányban a szülők foglalkozásai kerülnek bemutatásra.

b) Második rész

A pályaválasztási döntésük mögött munkáló tényezők feltárásához szükséges információkra irányultak, melyeknek prezentálása az alábbiakra szükül:

- A pályaválasztási döntéshozatal idején a családon belül vagy ismerősi/baráti körben már foglalkoztatott egészségügyi dolgozó jelenléte, foglalkozásának megnevezése,

- hallgató életkora, mikor meghozta pályaválasztási döntését,

- pályaválasztási elképzelésének határozottsága.

\section{Eredmények}

\section{Kategóriák megjelölése}

Szülők jelenlegi foglalkozása. A szülői foglalkozások csoportosításának vázát a Foglalkozások Egységes Osztályozási Rendszerének kategóriái adták. Az első kategóriát a gazdasági, igazgatási, érdekképviseleti vezetők adják, és a kategóriába tartozik minden olyan foglalkozás, amelyekben a szülő vezetői feladatköröket lát el. A második kategóriát felsőfokú képzettség önálló alkalmazását igénylő foglalkozások köre alkotta (a vizsgált hivatásokon túli humán-egészségügyi társfoglalkozások, felsőfokú végzettséghez kötött szociális szolgáltatási foglalkozások, oktatók és pedagógusok, pénzügyi és számviteli, mérnöki, jogi és társadalomtudományi, vallási, kulturális és sporttal kapcsolatos foglalkozások). A harmadik kategóriát kereskedelmi, szolgáltatási, pénzügyi foglalko- 
zások és az ügyintézők képezik. Ide tartoztak mindazon foglalkozások, amelyek kereskedelmi és vendéglátó-ipari (kereskedő, bolti eladó, szakács, cukrász, vendéglős), személyszolgáltatási (fodrász, kozmetikus), személygondozási (dajka, segédápoló, házi gondozó), jegykezelői, személy- és vagyonvédelmi területekhez (rendőr, tűzoltó, vagyonőr) tartoznak. A negyedik kategóriába tartoznak az irodai és ügyviteli (titkárnő, gépíró, könyvelö, analitikus könyvelö, bérelszámoló, postai dolgozók) és az ügyfélkapcsolati foglalkozások (banki ügyintéző, ügyfél-vevő tájékoztató, ingatlanszervező, recepciós). Az ötödik kategória az ipari, mezőgazdasági foglalkozásúak és technikusok elnevezést kapta. A kategóriába tartoztak a specifikus ügyintézők, az élelmiszeripari (húsfeldolgozó, pék), könnyüipari (szabó, esztergályos, nyomdász), fém-, és villamosipari (lakatos, hegesztő, kovács, gépjármü-és motorkarbantartók, villamos gépek karbantartói) és építőipari (kőmüves, ács, asztalos, vezeték- és csőhálózat szerelö, villanyszerelő, festő és mázoló) foglalkozások. A mezőgazdasági területről a növénytermesztési, állattenyésztési és állatgondozási, vegyes profilú gazdálkodók, erdőgazdálkodók adták és a specifikus technikusok is ide lettek sorolva. A hatodik csoport a gépkezelök és jármüvezetők. Ide tartoztak a feldolgozóipari a feldolgozóipari gépek kezelöi, és a jármüvezetők. A hetedik kategóriát a szakképzettséget nem igénylő (egyszerü) foglalkozások jelentik (takarítók és kisegítők, szemétszállítók és utcaseprők, portások és parkolóőrök). A nyolcadikba a vállalkozók, a kilencedikbe pedig azok a szülök kerültek, akik jelenleg munkanélküliek, háztartásbeliek, vagy nyugalmazottak, illetve azok a válaszok, melyeket a fentebbi csoportokba nem lehetett besorolni a foglalkozások pontatlan körülírása végett.

Hallgatók családjában vagy ismerősi/baráti körében megjelenő, már foglalkoztatott egészségügyi dolgozók. Azoknak a hallgatóknak, akiknek a pályaválasztási döntéshozataluk idején családjában volt egészségügyi dolgozó, családon belüli státusz és az egészségügyi rendszerben betöltött foglalkozási szerep mentén csoportok alakultak. Családon belüli státusz alapján elkülönítve lett az anya, apa, testvér, nagyszülö, keresztszülö és más családtag. Más családtag kategóriába tartoztak azok a családtagok, amelyeket a hallgató annak tart, viszont szakirodalmi szempontból „távolinak” bizonyulnak.

Egészségügyi rendszerben betöltött foglalkozási szerep mentén az ápoló, asszisztens és mütőssegéd, orvos, mentőtiszt, szülésznő, más mentődolgozó (mentőgépkocsivezető, mentőápoló) hivatások kerültek csoportosításra. Az egyéb egészségügyi dolgozók kategóriába tartoznak azok a foglalkozások is, amelyek nem képezik szerves részét FEOR beosztás alapján a standard egészségügyi kategóriának vagy egyéb humán-egészségügyi társfoglalkozások (pszichológus, intézményvezető, szociális gondozó, védőnő, gyógytornász, gyógy-masszőr, fogtechnikus), viszont a hallgatók annak tartják számon.

Pályaválasztási döntéshozatal idejének csoportositása. A pályaválasztási döntéshozatal idejének megjelölése a kérdőívben nyílt kérdésként szerepelt. A kapott életkorokat a mai magyar iskolarendszerben történő pályaválasztási döntéshozatal idejének megfelelöen csoportosítottam, ennek megfelelően 3-13. életév köztit korai, 14-19. életév köztit normál, 19-30. életév köztit késői pályaválasztási döntésidőszaknak vettem. 


\section{Pályaválasztási döntéshozatal idején jelen lévő egészségügyi mintaképek}

A kutatás során a pályaválasztási döntéshozataluk idején már foglalkoztatott egészségügyi dolgozói mintakép jelenlétéről kérdeztem a hallgatókat.

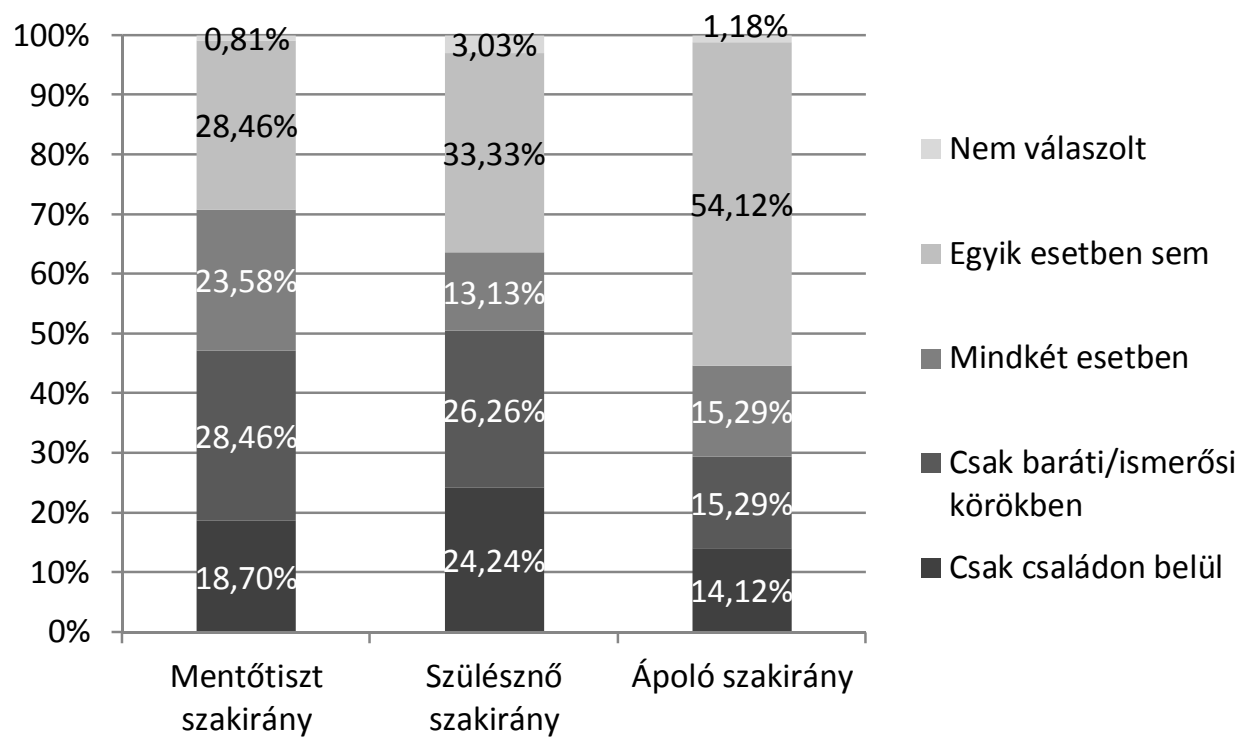

1. ábra. Foglalkoztatott egészségügyi dolgozók a pályaválasztási döntés előtt álló fiatal környezetében.

A serdülő pályaválasztási döntéshozatalát jelentősen megkönnyíti, hogyha környezetében él, illetve talál egy olyan személyt, aki szakmai-érdeklődési irányának megfelelő pozíciót tölt be, hiszen így olyan (akár személyesebb) információkhoz juthat az orientálódás során, amely leginkább passzol a választási alternatívájához. Ez fontos, hiszen egy szakma szélesebb körü feltérképezése csökkenti a pályaelhagyás kockázatát, különösen a zártabb rendszerü hivatások esetében.

Az elsődleges szocializáció miatt először családja, elsősorban szülei foglalkozásaival ismerkedik meg, majd az intézményekbe, közösségekbe történő belépést követően ez a szakma-paletta folyamatosan bővül, növelve a pályalehetöségeket.

Az eredmények azt mutatják (1.ábra), hogy a mentőtiszt hallgatók 18,70 százalékának csak családján belül, 28,46 százalékának csak baráti/ismerősi körében, 23,58 százalékának mindkét esetben, viszont valamivel több, mint negyedük elött (28,46\%) egyáltalán nem volt egészségügyi mintakép döntéshozataluk idején.

Ez a szülésznő hallgatók 24,24 százaléknak csak családjában, 26,26 százalékának csak baráti és ismerősi körében, 13,13 százalékának mindkét esetben, 33,33 százalékának pedig egyik esetben sem figyelhető meg. Az ápoló hallgatók több mint fele $(54,12 \%)$ nem ismert egészségügyi dolgozót, mikor pályája mellett elköteleződött. 14,12 százalékuknak csak családjában, 15,29 százalékuknak csak baráti/ismerősi körében dolgozott valamilyen egészségügyi pozícióban rokona vagy barátja. 
A szakirányok összevetése során láthatjuk, hogy a legnagyobb arányban a mentőtiszt hallgatók rendelkeztek egészségügyi mintaképpel, legkevésbé pedig az ápoló hallgatók, melyet a vizsgált hivatások ,láthatóságával” és a hivatáson belüli mozgástér határaival lehet magyarázni. Ebből következik, hogy az ápolói hivatással kapcsolatos következtetések levonásakor megfontoltnak kell lenni, mivel egy gyógyintézet különböző osztályain is betölthetnek pozíciót, ezáltal az ápoló-laikus/beteg/sérült interakció gyakoribb, vagyis a hivatással kapcsolatos tapasztalatok száma is magasabb. A láthatóságnak köszönhetően pedig munkafolyamataikba is nagyobb betekintést nyerhetnek a kívülállók. Ezzel szemben a szülésznő, mentőtiszt foglalkozások szakmán belüli mozgástere jóval korlátozottabb, valamint terület-specifikációjuk miatt (első esetben szülészet-nőgyógyászat, második esetben sürgősségi prehospitális betegellátás) kevésbé is vannak szem elött, emiatt a munkafolyamatok is „rejtettebbek”, a tapasztalatok száma is alacsonyabb.

\section{Az ápoló, szülésznő, mentőtiszt hallgatók családi háttere}

\section{Egészségügyi foglalkozású családtagok}

A szülők foglalkozásának elemzése során külön csoportba kerültek azoknak a hallgatóknak a szülei, akik az egészségügyben dolgoznak, továbbá összevetésre kerültek családon belül elfoglalt helyük és egészségügyi pozíciójuk szerint is.

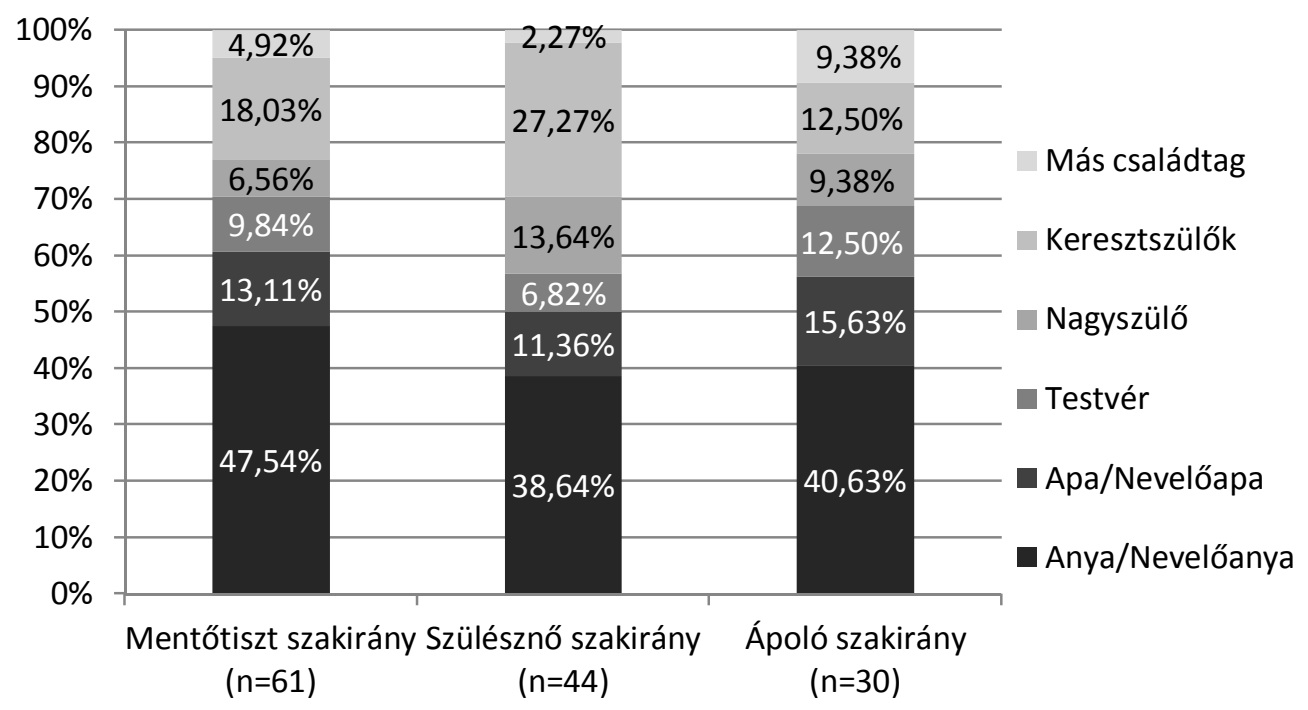

2. ábra. Foglalkoztatott egészségügyi dolgozók a családban elfoglalt helyük szerint

A pályaválasztási kutatások során elengedhetetlen feltérképezni a gyermek családi hátterét, hiszen a státuszreprodukció szerves elemét képezi a származás, és az általa megszerezhető társadalmi pozíció, kulturális tőke és e kettő kapcsolata (Blau-Duncan, 1967). A társadalom és a munkaerőpiac átalakulása általánossá tette a női munkavállalását, a korábban merevebb családon belüli nemi szerepek fellazulásával az elmúlt évek tapasztalatai azt mutatják, hogy egy család társadalomban elfoglalt pozíciójának 
vizsgálata nem történhet meg az anyai szerep figyelembevétele nélkül. A család kulturális klímájával kialakításában az anya szerepe kiemelendő, hiszen a tradicionális nemi szerepekben a gyermeknevelés feladatát még mindig az anyai hatáskörbe foglalják. E klíma, különös tekintettel a kulturális beállítottság alakulását az iskolai végzettsége határozza meg, ami a gyermek mobilitási esélyeire, továbbtanulási elképzeléseire, aspirációira is hatással van. Így kijelenthető, hogy az anya foglalkozása egyaránt hatással van a gyermek későbbi pozíciójára (www1).

Az eredmények azt mutatják (2. ábra), hogy a mentőtiszt hallgatók közel felének, (42,28\%), a szülésznő hallgatók 37,37 százalékának, és az ápoló hallgatók több mint negyedének $(29,41 \%)$ családjában (is) megjelent az egészségügyi mintakép.

Mivel a pályaválasztási döntéshozatal és az identitás kialakítása Erik. H. Erikson elmélete szerint egyazon időszakra, vagyis a serdülőkorra tehető, a szülők pszichoszociális szerepe a pályaválasztás során egyértelműen meghatározó, hiszen ők azok, akik a leginkább részesei voltak a gyermek fejlődési fázisainak, valamint segíthetik a serdülőt a figyelmének fókuszába került szakmák letisztázásában (N. Kollár-Szabó, 2004), ezáltal a pályaidentifikációban, különös tekintettel a serdülö későbbi foglalkozási szerepeiben való önmegvalósításban egyaránt (Ritoókné, 1986). Így az identitás (beleértve a pályaidentitást is) kialakulását meghatározza a serdülő környezete, ezért bizonyos szocializációs tényezők befolyásolhatják az elköteleződést, kiemelve a serdülő erős azonosulását szülőjével. (Waterman, 1982 id. Szabó, 2006).

Az adatok azt mutatják, hogy az egészségügyi mintaképet mindhárom szakirány hallgatóinak esetében az anya adja. Ez a mentőtiszt és ápoló hallgatók esetében különösen hangsúlyos, hiszen közel minden második válaszadó édesanyja valamilyen egészségügyi pozíciót tölt be (első esetben 47,54\%, második esetben 40,63\%). A jelenség a szülésznő hallgatók 38,64 százalékánál figyelhető meg. Ehhez képest az apák, mint egészségügyi mintaképek, jóval kisebb százalékban fordul elő: a mentőtiszt hallgatók 13,11, ápoló hallgatók 15,63 és szülésznő hallgatók 11,36 százalékánál (2. ábra).

Láthatjuk, hogy a mentőtiszt és szülésznő hallgatók esetében körülbelül háromszor, ápolók esetében kétszer gyakoribb az anyai egészségügyi mintakép, mint az apai. Míg az egészségügyi pozíciók és a nemi arányok kapcsolata azzal magyarázható, hogy az egészségügyi pozíciókat többségében nők töltik be, addig a szülő foglalkozási területének megfelelő pálya választása Honess (2001) elméletével magyarázató, miszerint a serdülő szülője nézeteit, és a további családtagok percepcióit pontosan észlelik, és magas összhangot mutat jövőbeni munkáját illetően. Éppen ezért a vizsgálat során nemcsak az egészségügyi foglalkozású szülők, hanem a testvérek, valamint a tágabb családtagok jelenléte is figyelembe lett véve.

Ez esetben a keresztszülői bizonyult a leggyakoribbnak a hallgatók körében (mentőtiszt hallgatóknál 18,03\%, szülésznő hallgatóknál 27,27 százalék, ápoló hallgatóknál 12,50 százalék), melyet a testvéri és nagyszülői mintakép követ. A szakirányok összevetése során azt tapasztaljuk, hogy míg a mentőtiszt és ápoló hallgatóknál a testvéri $(9,84 \%$ és $12,50 \%)$, addig a szülésznő hallgatóknál a nagyszülői példa mutatkozik meg nagyobb arányban $(13,64 \%)$ (2. ábra). 


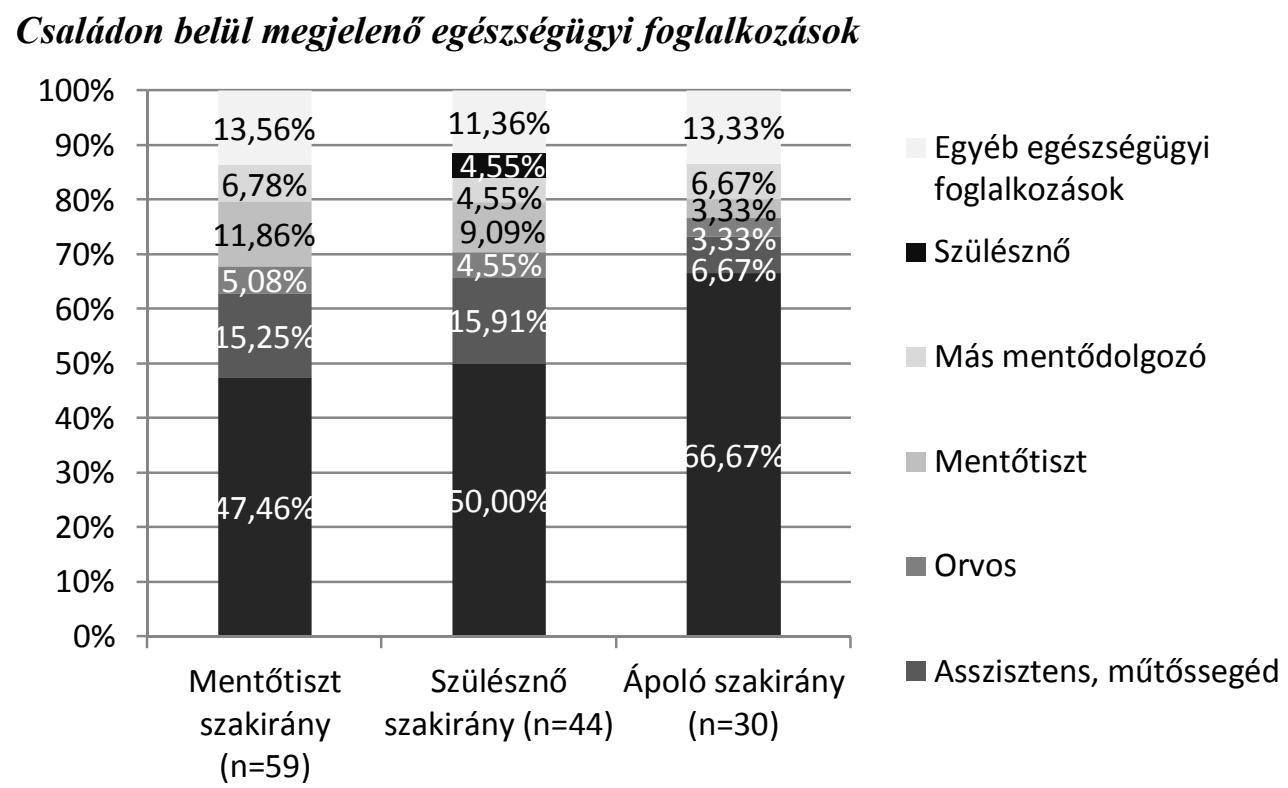

3. ábra. Egészségügyi foglalkozások előfordulása a hallgatók családjain belül.

Mivel az egyén életpálya alakulását befolyásolja a szülő munkamegosztási pozíciója (Coleman, 2000), valamint a szülö foglalkozása és munkahelyének sajátossága összefüggésben van a gyermek terveinek egyértelmüségével (Pulkinnen, 1990), így az elemzés során nem csak a mintaadót, hanem a betöltött foglalkozási szerepét is figyelembe vettem. Mindhárom szakirányt tekintve a családon belül megjelenő leggyakoribb egészségügyi foglalkozás az ápoló hivatás (mentőtiszt hallgatók 47,46\%-a, szülésznő hallgatók 50,00\%-a, ápoló hallgatók 66,67\%-a), ezáltal az ápoló hivatást tekinthetjük egyfajta „belépő” hivatásnak az egészségügyi rendszerbe. (3. ábra)

A mentőtiszt és szülésznő hallgatók esetében a második leggyakoribb foglalkozás az asszisztensi, mütőssegéd mutatkozik (első esetben 15,25\%, második esetben 15,91\%), az ápoló hallgatóknál egyenlő százalékos arányban mutatkozik meg az mentődolgozói foglalkozásokkal.

A szakirányok összevetése során nagyobb százalékban jelenik meg a családban az egészségügyi foglalkozás, ami azonos a hallgató pályaválasztásában. Vagyis, a mentőtiszti hivatás a mentőtiszt (11,86\%), a szülésznői hivatás (egyedüliként) a szülésznő (4,55\%), az ápoló hivatás pedig az ápoló hallgatóknál $(66,67 \%)$ jelenik meg a legnagyobb százalékban.

\section{Nem egészségügyi munkakört betöltő szülök foglalkozása}

Azoknak a hallgatóknak, kinek szülei nem egészségügyi, hanem más területen dolgoznak, mindkét szülö foglalkozása a FEOR struktúra mentén lett csoportosítva. 


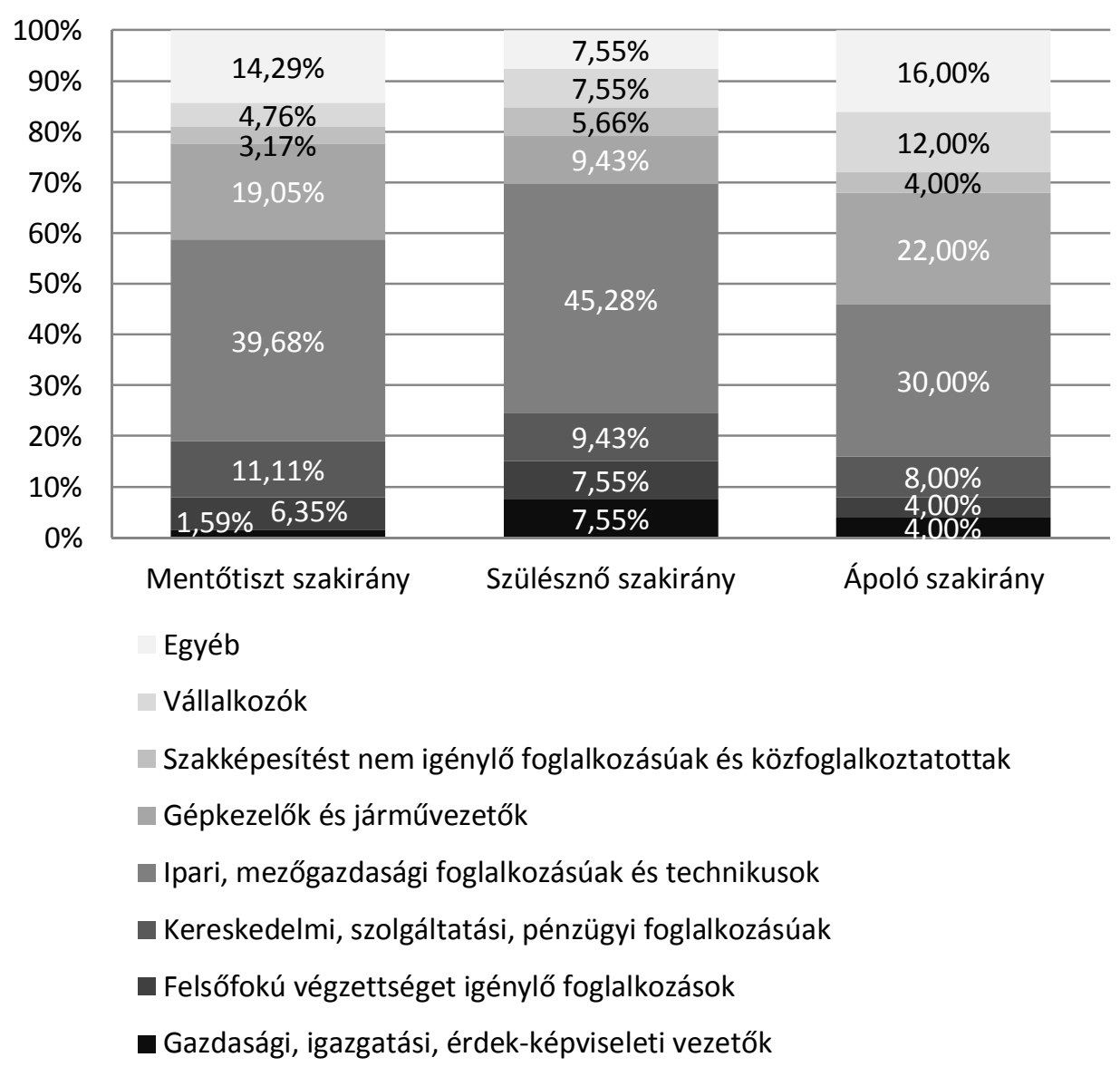

4. ábra. A nem egészségügyi munkakört betöltő apák foglalkozása

Az eredmények azt mutatják (4. ábra), hogy az apák foglalkozását tekintve a mentőtiszthallgatók esetében a leginkább az ipari, mezőgazdasági és technikusi munkakörök fordultak elő $(39,68 \%)$, melyet a gépkezelők és jármüvezetők követtek (19,05\%). 11,11 százalékuk kereskedelmi, szolgáltatási, pénzügyi, 6,35 százalékuk felsőfokú végzettséghez kötött munkaköröket tölt be. 4,76 százalékuk vállalkozó, 1,59 százalékuk gazdasági, igazgatási, érdekképviseleti vezetö. A többi szakirány hallgatóihoz képest náluk jelenik meg a legkisebb százalékban az apák foglalkozását tekintve a szakképesítést nem igénylö munkakörben dolgozók és a közfoglalkoztatottak százalékos aránya $(3,17 \%)$.

A szülésznő hallgatóknál ugyancsak az ipari, mezőgazdasági és technikusi munkakörök jelentek meg a legnagyobb mértékben az apák foglalkozását tekintve $(45,28 \%)$. 9,43 százalékuk gépkezelő vagy gépjármüvezető, 7,55 százalékuk felsőfokú végzettséget igénylő foglalkozású. 9,43 százalékuk kereskedelemben, szolgáltatóiparban, pénzügyi területen dolgozik, 7,55 százalékuk pedig vezetőként, vállalkozóként. A szakirányok összevetése során a szülésznő hallgatók apáinál fordult elő a 
legnagyobb százalékban a szakképesítést nem igénylő foglalkozások és közalkalmazotti munkakörök betöltése (5,66\%).

Az ápoló hallgatók apáinak 30,00 százaléka ipari, mezőgazdasági vagy technikusi munkakörben dolgozik, 8,00 százaléka kereskedelemben, szolgáltatóiparban vagy pénzügyi területen. A mentőtiszt és szülésznő hallgatókhoz képest náluk jelenik meg a legnagyobb százalékban az egyéni vállalkozás (12,00\%). Ugyanakkora százalékban fordul elő a felsőfokú képzettséget igénylő foglalkozásúak, a vezetők, és a szakképesítést nem igénylő foglalkozásúak és közfoglalkoztatottak aránya ( $4,00 \%$ az említett esetekben).

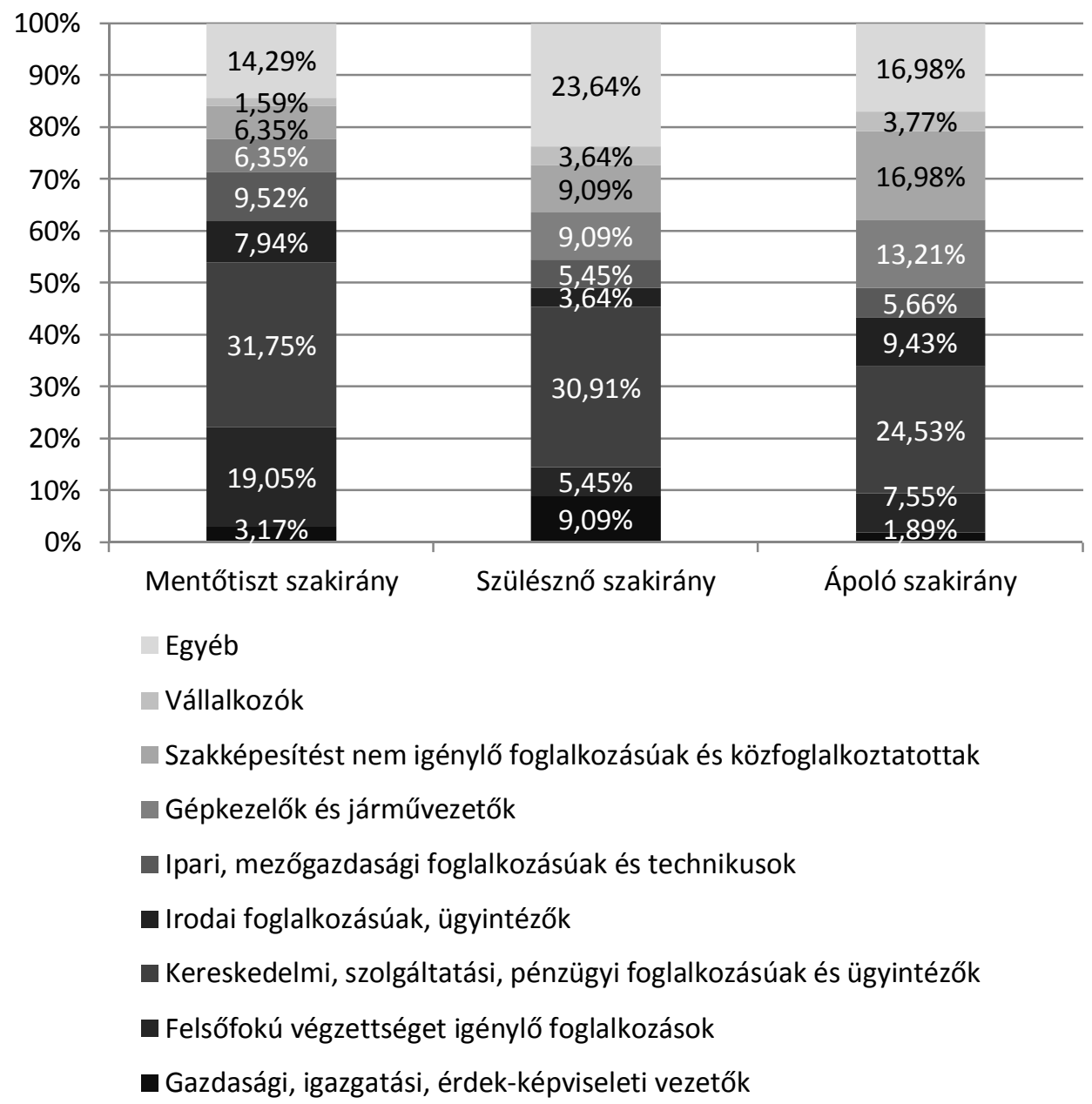

5. ábra. Nem egészségügyi munkakörtbetöltő anyák foglalkozása.

Az anyák foglalkozását megjelenítő diagramon (5. ábra) láthatjuk, hogy mindhárom szakirány hallgatóinak esetében az anyák inkább a kereskedelemben, pénzügyi területen illetve a szolgáltatóiparban dolgoznak (mentőtisztek esetében 31,75 \%-ban, szülésznő hallgatóknál 30,91\%-ban, ápoló hallgatóknál 24,53\%-ban). 
A mentőtiszt hallgatók anyáinál fordul elő a legnagyobb százalékban az, hogy valamilyen felsőfokú végzettséghez kötött foglalkozási pozíciót töltenek be (19,05\%). 7,94 százalékuk irodai és ehhez tartozó ügyintézői feladatokat, 9,52 százalékuk ipari, mezőgazdasági területen és technikusként, 6,35-6,35 százalékuk gépkezelőként, jármüvezetőként, illetve szakképesítést nem igénylö területen vagy közfoglalkoztatottakként dolgoznak. Csupán csak 1,59 százalékuk dolgozik saját vállalkozásukon belül, 3,17 százalékuk pedig valamilyen vezetöként.

A szülésznő hallgatók esetében egyenlő százalékos arány mutatkozik a vezetői, gépkezelői és jármüvezetői és szakképesítést nem igénylő vagy közfoglalkoztatott pozíciók közt (9,09\%). A felmérésben részt vett hallgatók anyáinak 3,64 százaléka vállalkozó, 5,45 százaléka ipari vagy mezőgazdasági foglalkozású vagy technikus. Az ápoló és mentőtiszt hallgatók anyáihoz képest náluk fordul elő a legkisebb százalékos megoszlásban valamely felsőfokú végzettséget igénylő pozíció betöltése $(5,45 \%)$.

Az ápoló hallgatók anyáinak 13,21 százaléka gépkezelőként vagy jármüvezetőként dolgozik, 16,98 százaléka pedig szakképesítést nem igénylő vagy közfoglalkoztatott pozícióban, ami a másik két szakirányhoz viszonyítva mindkét esetben a legmagasabb százalékos arány. 5,66 százalékuk ipari, mezőgazdasági területen, 3,77 százalékuk vállalkozóként, 1,89 százalékuk valamilyen vezetőként, 7,55 százalékuk pedig valamilyen felsőfokú végzettséget igénylő foglalkozási körben keresi meg jövedelmét.

Az egyéb kategóriát mind az apák mind az anyák esetében azok a válaszok adták, melyeket a hallgatók vagy körülírtak, vagy csak a foglalkozás nagy vonalakban történő besorolását fogalmazták meg, ennek okán a FEOR struktúrát adó kategóriákba való téves elhelyezést elkerülve, külön csoportot képeztek. Az egyéb kategória további bontása az alacsony al-alminták és elemszámok végett nem történt meg, így a kategória „sokszínüsége” végett az erre vonatkozó következtetések megfogalmazása is megfontolandó.

\section{A hallgatók továbbtanulása mögött munkáló tényezők}

\section{Egészségügyi dolgozói mintakép a baráti/ismerösi körben}

Fontos figyelembe venni, hogy a „szignifikáns másik” nem csak a családon, hanem akár a baráti/ismerősi körben is megtalálható.

A mentőtiszt hallgatók 52,04 százaléka válaszolta azt, hogy volt olyan ismerőse vagy barátja, aki akkoriban az egészségügyben dolgozott (6. ábra). 43,04 százalékának mentőtisztként dolgozó, 6,33 százalékának más mentőszolgálati pozíciót betöltő, 34,18 százalékának ápolói, 11,39 százalékának orvosi, 3,80 százalékának aszszisztensi vagy mütőssegédi foglalkozású barátja vagy ismerőse volt pályaválasztási döntéshozatalakor. 


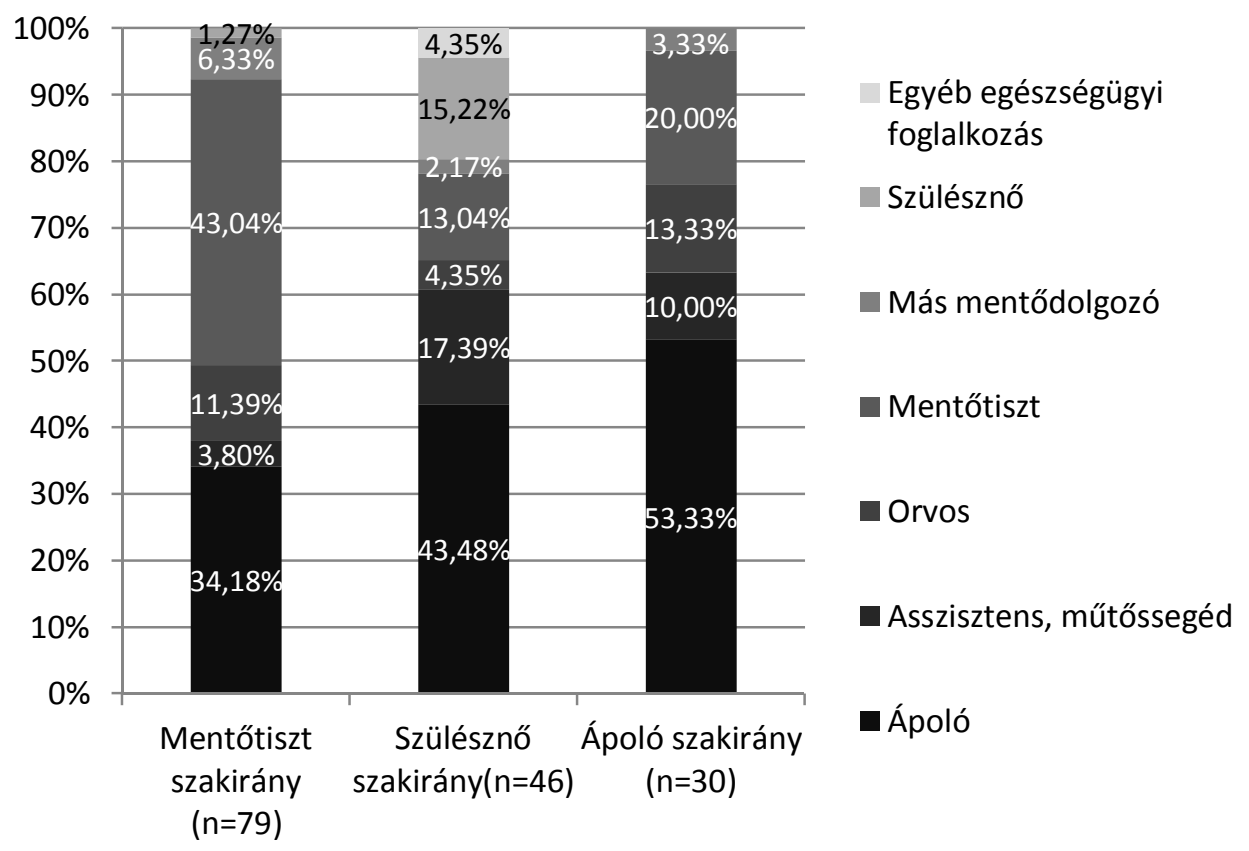

6. ábra. Egészségügyi foglalkozások megjelenése a hallgatók baráti/ismerösi köreiben

Mint ahogy az 1. ábrán is láttuk, a szülésznő hallgatók 39,39 százalékánál fordult elő egészségügyi foglalkozású barát vagy ismerős elköteleződésük idején. A 6. ábra mutatja, hogy náluk jelenik meg a legnagyobb mértékben a szülésznői minta baráti/ismerősi körökben is $(15,22 \%)$. 43,48 százalékuknak ápolóként, 17,39 százalékuknak asszisztensként vagy mütőssegédként, 13,04 százalékuknak mentőtisztként, 2,17 százalékuknak mentőápolóként vagy mentőgépkocsi-vezetőként (más mentődolgozó kategória), 4,35 százalékuknak orvosként dolgozó ismerőse volt.

Az ápoló hallgatók csupán 30,58 százalékának volt jelen egészségügyben foglalkoztatott barátja pályaválasztásukkor (v.ö. 1. ábra). Noha ők rendelkeztek a legkevésbé dolgozói mintaképpel, barátaiknak vagy ismerőseiknek 53,33 százaléka ápolóként, 20,00 százaléka mentőtisztként, 3,33 százaléka más mentőszolgálati képviselőként, 13,33 százaléka orvosként, 10,00 százaléka asszisztensként vagy mütőssegédként volt foglalkoztatva (6. ábra).

Az eredmények azt mutatják, hogy nagyobb arányban jelent meg pályaválasztási döntésük idején a hallgatók baráti köreiben választott hivatásukkal azonos foglalkozást üző barát, mint családjukban (ahol inkább az ápoló hivatás jelenik meg leggyakrabban).

\section{A döntés életkora}

A korai pályaválasztási döntéshozatal a vizsgálatban részt vett szakirányokhoz képest a mentőtiszt hallgatóknál mutatkozott meg a nagyobb százalékban, 17,89 százalékuk 3-13 éves kora között köteleződött el választott hivatásuk mellett. Ennek egyik magyarázata az, hogy a mentőtiszt hallgatóknál fordult elö (a többi szakirányhoz képest) a leggyakrabban a családon és ismerősi körön belüli egészségügyi min- 
taadó, vagyis ők azok, akik leginkább rendelkeztek a szakmabelépés előtt „,személyesebb" tapasztalattal. Ez a szülésznőknél csak 6,25 százalékban, ápolóknál 5,95 százalékban fordult elö (7. ábra).

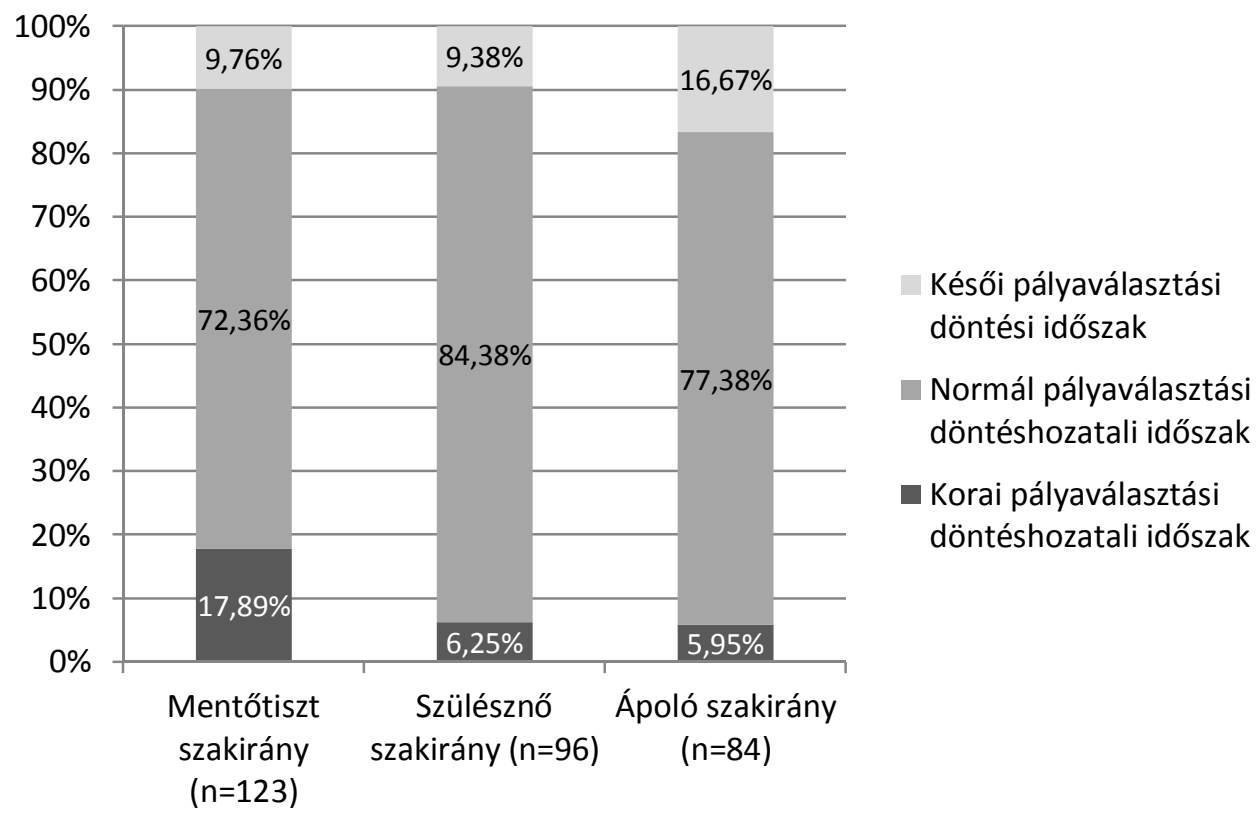

7. ábra. Választott szakirány melletti döntés életkori felosztásban.

Mégis a normál pályaválasztási döntéshozatal volt a leggyakoribb mindhárom szakirány esetében, a mentőtiszt hallgatók 72,36 százaléka, szülésznő hallgatók 84,38 százaléka, ápoló hallgatók 77,38 százaléka hozta meg döntését 14-19 éves korában. A késői pályaválasztási döntéshozatal az ápoló hallgatóknál jellemzőbb (16,67\%), szülésznők 9,38 százaléka, mentőtisztek 9,76 százaléka választotta leendő hivatását 2030 életéve közt.

\section{A pályaválasztási döntés határozottsága}

A mentőtiszt hallgatók esetében láthatjuk (8. ábra), hogy a hallgatók közel fele a pályaválasztási döntés időszakában pontosan tudta, merre és milyen irányban szeretné tanulmányait folytatni $(45,53 \%)$. Ez a vizsgált szakirányok tekintetében egyedüliként mondható, hiszen a szülésznő és ápoló hallgatók többsége csak körülbelül tudta, mit szeretne a későbbiekben tanulni (előbbi esetben 59,60 százalékuk, utóbbi esetben 51,76 százalékuk). A szakirányok válaszait összevetve a legnagyobb százalékos megoszlásban az ápoló hallgatóknál figyelhető meg, hogy egyáltalán nem voltak határozott elképzeléseik továbbtanulásuk szempontjából (16,47\%). Ez a szülésznő hallgatók 11,11 százalékánál, legkisebb mértékben a mentőtiszt hallgatók 8,94 százalékánál fordult elő. 


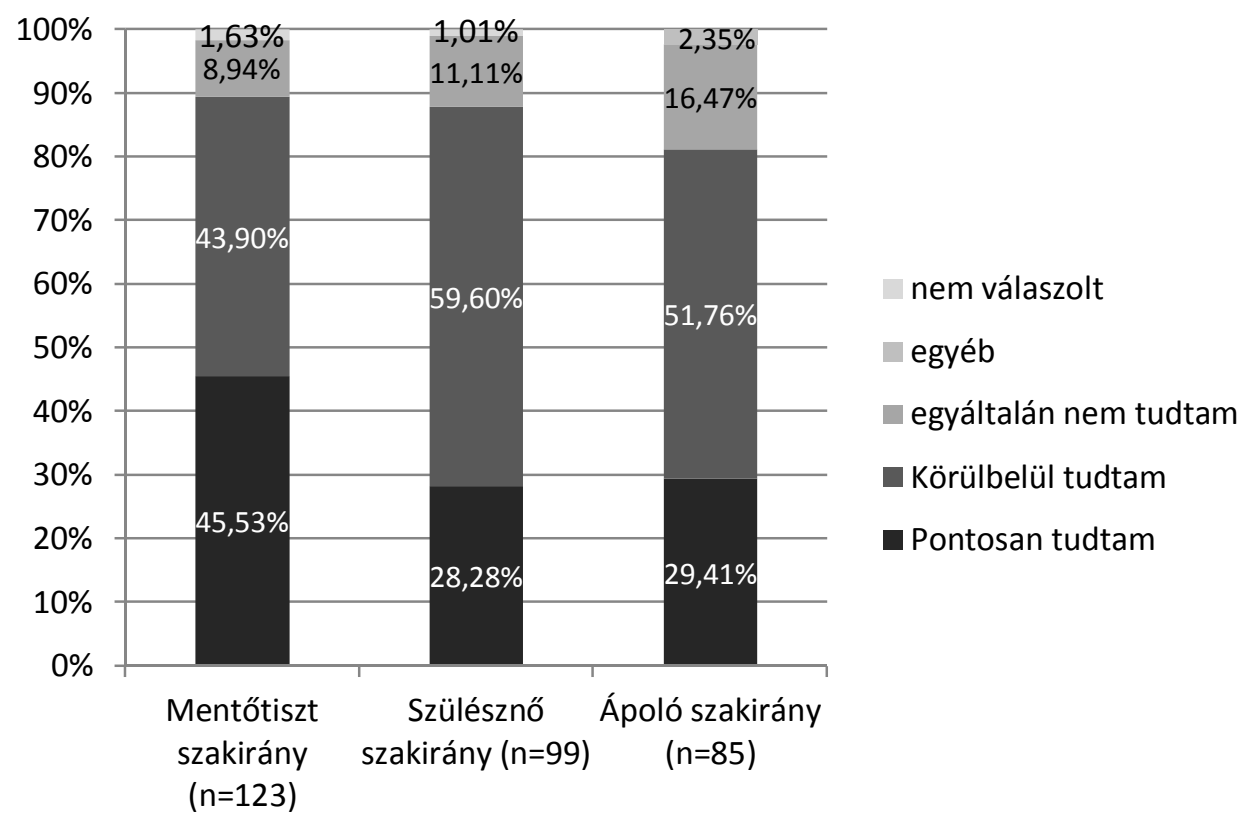

8. ábra. Pályaválasztási elképzeléseiknek határozottsága.

\section{Összegzés}

A pályaválasztásuk mögött munkálódó tényezők feltárására szolgáló eredmények azt mutatják, hogy a korai pályaválasztási döntéshozatal a mentőtisztek esetében nagyobb arányban megmutatkozik, mint a szülésznő vagy ápoló hallgatóknál. Összességében elmondható, hogy mindhárom szakirány esetében a legtöbb hallgató választott hivatása melletti elköteleződését a normál pályaválasztási időszakban hozta meg. A mentőtisztek között láthatók leginkább azok a hallgatók, akik egészen pontosan tudták, milyen irányban szeretnék tanulmányaikat folytatni. Az ápoló hallgatóknál kétszer gyakoribbnak bizonyult a pályaválasztási döntés meghozatalának nehézsége, mint a mentőtiszt hallgatóknál, a szülésznő hallgatók nagy részének elképzelései inkább csak körülbelül rajzolódtak ki.

A mentőtiszt és szülésznő szakirány hallgatók közel felének van a családjában már egészségügyi dolgozó, míg az ápolók csupán egy harmada mondhatja ezt el magáról. Úgy tűnik, az ápoló hivatás szolgál leginkább belépő kapuként az egészségügyi foglalkozások területére. A legmeghatározóbb családi mintaadó mindhárom szakirány esetében az anya. A legelterjedtebb családon belüli egészségügyi pozíciónak a mentőtiszt hallgatók közel felénél, szülésznő hallgatók felénél, ápoló hallgatók több mint felénél az ápoló hivatás mutatkozott. A mentőtiszt hivatás a mentőtiszt hallgatók, a szülésznői hivatás a szülésznő hallgatók, az ápoló hivatás pedig az ápoló hallgatók családjában figyelhető meg a legnagyobb mértékben. Ellenben a hallgatók pályaválasztási döntéshozataluk idején a saját szakirányával megegyező foglalkozású bará- 
taik/ismerőseik százalékos aránya magasabbnak mutatkozott, mint a családban elöfordulóé, önmagában viszont ez csupán csak előfeltételezi a kortársak hatásának erősségét a család hatásával szemben. A nem egészségügyi munkakört teljesítő apák esetében mindhárom szakirányt tekintve az ipari, mezőgazdasági és technikusi foglalkozások értéke kimagasló, melyet a gépkezelők és jármüvezetők követnek, az anyák esetében pedig a kereskedelmi, szolgáltatási, pénzügyi és ügyintézői területek pozícióinak betöltése a leggyakoribb. Míg az apák esetében a felsőfokú végzettséget igénylö munkakörök betöltése a szülésznő hallgatóknál gyakoribb, az anyáké a mentőtiszt hallgatóknál mutatkozik meg.

\section{Irodalomjegyzék}

1. Banton M. (1965): Roles. An Introduction to the Study of Social Relations. London.

2. Betlehem J. (2012): Mi a Sürgősségi Akadémia szerepe az egészségügyi ellátás fejlesztésében? http://demin.hu/files/userfiles/ DEMIN_XI/ deminXI-doc/ deminXI-21-doc.pdf (látogatás: 2017.12.11.)

3. Boudon R. (1974): Education, Opportunity and SocialIneqality: ChangingProspects in Wastern Society. New York, Wiley.

4. Blau, P. M. -Duncan O. D. (1967): The American Occupational Structure, Wiley, 163-177. Magyarul megjelent: Róbert Péter (szerk.) A társadalmi mobilitás. Budapest: Új Mandátum, 1998, 141-152.

5. Burányné R. E. - Kun R.-né (2015): A továbbtanulási, pályaválasztási tanácsadás szakszolgálati protokollja. Educatio Társadalmi Szolgáltató Nonprofit Kft., Budapest.

6. Coleman, J. S. (2000): Foundatons of SocialTheory, The Belknap Press of Harvard University Press, Cambridge, Masachussetts, and London, England.

7. Csepeli Gy. (1997): Szociálpszichológia. Osiris Kiadó. Budapest.

8. Csepeli Gy. (2001): Szociálpszichológia. Osiris Kiadó, Budapest.

9. Farkas I., Albert J., Leveleki M. (2014): Szociológia. Möbius Kiadó, Nyíregyháza.

10. Felsman, D. R. és Bluestein, D. L. (1999): The role of peerrelatedness in lateadolescentcareerdevelopment. Journal of VocationalBehavior, 54. sz. pp. 279-295.

11. Fodorné-Zagyi O., Zagyi B.(2004): Helyzetkép az egészségügy humánerőforrásellátottságáról, különös tekintettel az oktatásra. Egészségügyi Gazdasági Szemle 4., pp. 24-32.

12. Guay, F., Senecal, C., Gauthier, L. és Fernet, C. (2003): Predicting career indecision: A self determination theory perspective. Journal of CounselingPsychology, 50. 2. sz. pp.165-177.

13. Hetherington E. M, Cox M., Cox R., Stevens J. H., Jr, Matthews M. (1978): Mother-child, father-child relations. National Association for the Education of Young Children; Washington, The aftermath of divorce; pp. 149-176. 
14. Honess, T. (2001): Future-orientation and meta-cognition in familytriads. - Elöadás az Európai Fejlődéslélektani Társaság 10. Konferenciáján, aug. 22-26. Uppsala, Svédország.

15. Kajtor E. (2003): A magyar egészségügy humánpolitikai helyzete. Egészségügyi Gazdasági Szemle 5. sz. pp. 49-51.

16. Kupeczik É. (2018): Az ápolás-és betegellátás alapszakos hallgatók pályaválasztási aspirációiknak, pályaelhagyási kockázatuknak és a mentőtiszt, szülésznő, ápoló hivatások megítélésének feltárása. TDK dolgozat. DE EK, Nyíregyháza.

17. Kupeczik É., Hüse L. (2017): Az ápoló, mentőtiszt, szülésznő szak-irány pályaképe egészségügyi hallgatók és pályaválasztás elött álló középiskolai tanulók szemszögéből. „Hallgatók a tudomány útján” - Diáktudomány 2. DE EK, Nyíregyháza. 73-85.

18. Lannert J. (2004): Pályaválasztási aspirációk. Doktori értekezés. Budapesti Közgazdasági Egyetem Szociológia Ph.D. program, Budapest.

19. N. Kollár K., Szabó É. (2004): Pszichológia pedagógusoknak. Osiris Kiadó, Budapest.

20. Okiishi, R. W. (1987): The Genogramas a Tool in CareerCounseling, Journal of Counseling and Development, Vol 66. pp. 139-143.

21. Papula L. (2008): Mi leszel, ha nagy leszel? A pályaválasztást meghatározó tényezők. Bolyai Szemle 2006/2, pp. 33-44.

22. Pulkkinen, L. (1990): Home atmosphere and adolescentfutureorientation. European Journal of Psychology of Education, 5. 1. sz. pp. 33-43.

23. Sallay H. (2003): A szülői nevelés hatása a serdülő jövőorientációjának alakulására. Magyar Pedagógia, 103.évf. 3. sz. pp. 389-404.

24. Szelesné Árokszállási A. (2016): Rekrutáció és pályaszocializáció regionális öszszehasonlításban. Mentőtiszt szakirányok tanuló hallgatók érték-és pályaorientációja. Doktori Értekezés. Debreceni Egyetem BTK Humán Tudományok Doktori Iskola, Debrecen.

25. Vajda Zs., Kósa É. (2005): Neveléslélektan. Osiris Kiadó, Budapest.

26. Zakar A. (1988) : Pályaválasztási elméletek. Tankönyvkiadó, Budapest.

Internetes forrás:

http://www.szociologia.hu/dynamic/9803blasko.htm\#06

Blaskó Zs. : Kulturális tőke és társadalmi reprodukció; Látogatva: 2018.04. 